\title{
ON THE JUBILEE OF THE MOSCOW STATE TECHNOLOGICAL UNIVERSITY STANKIN
}

2015 marks the 85th anniversary of the founding of the Moscow State Technological University Stankin (MGTU Stankin). Over these years, more than 55 thousand engineers, baccalaureates, and masters and about 2 thousand doctors and candidates in the sciences have passed through its halls. They have gone on to make inestimable contributions to the scientific and technological progress of Russia, as well as of foreign countries. The work of many teachers and graduates of the university has gained worldwide recognition and is fundamental to the scientific basis of modern machine building.

The Moscow Machine-Tool Institute (Stankin) was set up during the era when this country was being industrialized (1930) and played an outstanding role in preparing staff for newly formed branches of industry such as machine building and the manufacture of instrumentation. New scientific schools were created continuously at the institute as it developed (and these are now well known throughout the world), as well as new specialties and branches of science and technology.

At present, MGTU Stankin is a multiprofile technological university that combines 30 departments and tens of scientific centers, which are involved in multilevel preparation of staff in more than 60 areas and specialties, encompassing essentially the entire spectrum of problems involved in the creation of integrated flexible computerized machine-building systems. For many years, the university has headed the teaching and pedagogical group for education in the area of automated machine building, which includes more than 270 institutions of higher education in Russia. Of its many departments, the Department of Measurement and Information Systems and Technologies is directly involved with problems of metrology and measurement techniques.

The role and significance of metrological support has been increasing in connection with improvements in various technological processes and raising the quality of machine building.

In this jubilee collection of articles, we are publishing papers by leading teachers, graduate students, and undergraduate students of the university on current problems of metrological support for various modern machine building technologies. These articles discuss methods and means for evaluating the micro- and nano-scale surface quality (roughness) of machined pieces, the three-dimensional accuracy of multicoordinate measurement and metrological systems, thermographic temperature measurements, various techniques for diagnostics of technological processes for machining of work pieces, and monitoring techniques based on tunnelling microscopy and digital holography.

This collection of articles will be continued in the next issue of this journal.

Translated from Izmeritel'naya Tekhnika, No. 7, p. 3, July, 2015. 